\title{
Bias Gender Dalam Prestasi Akademik Siswa: Studi tentang Perbandingan Prestasi Akademik Siswa Laki-laki dan Perempuan di SMA 12 Bekasi
}

\author{
Rakhmat Hidayat \\ E-mail: rakhmat_123@yahoo.com, Universitas Negeri Jakarta
}

\begin{abstract}
Abtsrak: Artikel ini memiliki dua tujuan penulisan. Pertama, menjelaskan perbedaan prestasi akademik antara siswa laki-laki dan perempuan pada mata pelajaran Fisika, Sosiologi dan Bahasa Indonesia? Kedua, menjelaskan kecenderungan perbedaan prestasi akademik antara siswa laki-laki dan perempuan pada mata pelajaran Fisika, Sosiologi dan Bahasa Indonesia. Dapat disimpulkan bahwa pada mata pelajaran Fisika, perempuan mempunyai nilai yang lebih tinggi dibanding laki-laki. Pada mata pelajaran Sosiologi dan Bahasa Indonesia, tidak terdapat perbedaan yang signifikan antara laki-laki dan perempuan. Hasil penelitian ini dipengaruhi oleh perkembangan pola pikir atau perubahan nilai-nilai yang dianut masyarakat berkaitan posisi perempuan dalam masyarakat. Penelitian ini menggunakan pendekatan kuantitatif dengan metode analisis data sekunder (ADS). Metode pengumpulan data yang digunakan adalah metode dokumentasi. Perlu dilakukan sosialisasi gender sejak dini kepada pelajar tentang kesetaraan gender dalam upaya meminimalisir terjadinya bias gender.
\end{abstract}

Kata kunci: gender, prestasi, dan sosialisasi

\begin{abstract}
This article has two purposes for writing. Firstly, explain the differences in academic achievement between students of men and women on the subjects of Physics, Sociology and Indonesian? Secondly, to explain the tendency of academic achievement differences between boys and girls on the subjects of Physics, Sociology and Bahasa Indonesian. It can be concluded that the subjects of Physics, women have higher grades than men. On the subject of Sociology and the Indonesian language, there were no significant differences between men and women. The results of this study was influenced by developments or changes in the mindset that embraced the values of society regarding women's position in society. This study use a quantitative approach with secondary data analysis methods (ADS). Data collection method used is the method of documentation. It should be done early gender socialization to students about gender equality in an effort to minimize the occurrence of gender bias.
\end{abstract}

Key words: gender, achievement, and socialization

\section{Pendahuluan}

Ketimpangan perempuan dan laki-laki terjadi dalam berbagai bidang. Masalah ini merupakan masalah yang selalu terjadi di negara-negara yang masih memegang teguh struktur sosial patriarkis. Patriarki secara harfiah berarti kekuasaan bapak atau patriach yang pada mulanya berkembang dalam keluarga yang berada dibawah perlindungan sang bapak, seperti yang terdapat dalam extended family atau dalam kelompok-kelompok masyarakat di tempat laki-laki menjadi pemimpinnya (Suyanto dalam Bemmelen, et.al, 2000: 432). Dia (laki-laki) mempunyai kedudukan yang sentral pada saat seluruh kehidupan serta kegiatan anggota kelompok ditentukan oleh si pemimpin yang laki-laki tersebut. Laki-laki dianggap orang yang patut memimpin. Akibatnya, terjadi subordinasi terhadap perempuan dalam berbagai bidang dalam kehidupan masyarakat.

Hal itu pula yang terjadi di Indonesia. Meskipun secara formal dalam UUD 1945 hak lakilaki dan perempuan tidak dibedakan tetapi dalam kenyataannya sangat berbeda. Berbagai studi yang pernah dilakukan menjelaskan bagaimana ketimpangan dalam berbagai aspek selalu dialami kaum perempuan Indonesia. Sebagai gambaran saja, ketimpangan tersebut terjadi di antaranya dalam bidang politik. Studi yang dilakukan Cetro (2002) tentang keterwakilan perempuan di 
Indonesia dalam partai politik dan lembaga legislatif mencatat bahwa perempuan masih berada dalam subordinasi laki-laki. Hal itu terlihat dalam Tabel 1. kan negara lain, yaitu hanya berjumlah 11,3 persen. Bidang pendidikan juga mengalami hal yang sama. Secara de jure akses warga negara terhadap pendidikan formal dijamin negara.

Tabel 1. Keterwakilan perempuan Indonesia dalam lembaga politik formal

\begin{tabular}{|l|c|c|c|c|c|}
\hline \multirow{2}{*}{ Lembaga } & \multicolumn{2}{|c|}{ Perempuan } & \multicolumn{2}{c|}{ Laki-Laki } & \multirow{2}{*}{ Jumlah } \\
\cline { 2 - 5 } & Jumlah & Persen & Jumlah & Persen & \\
\hline MPR* & 18 & 9,2 & 177 & 90,8 & 195 \\
\hline DPR* & 45 & 9 & 455 & 91 & 500 \\
\hline MA* & 7 & 14,8 & 40 & 85,2 & 47 \\
\hline BPK* & 0 & 0 & 7 & 100 & 7 \\
\hline DPA* & 2 & 4,4 & 43 & 95,6 & 42 \\
\hline KPU* & 2 & 18,1 & 9 & 81,9 & 11 \\
\hline Gubernur (DATI I )* & 0 & 0 & 30 & 100 & 30 \\
\hline Bupati (DATI II)* & 5 & 1,5 & 331 & 98,5 & 336 \\
\hline Eselon I-III** & 1.883 & 7 & 25.110 & 93 & 16.993 \\
\hline Hakim ** & 536 & 16,2 & 2.775 & 83,8 & 3.311 \\
\hline PTUN** & 35 & 23,4 & 150 & 76,6 & 185 \\
\hline
\end{tabular}

Sumber: Cetro, 2002

Hal yang sama dapat dilihat dalam keterwakilan perempuan sebagai anggota legislatif. Dalam catatan politik Indonesia, keterwakilan kaum perempuan di DPR belum pernah mencapai kuota 30 persen anggota Dewan. Sejak reformasi bergulir sebelas tahun lalu, keterwakilan perempuan jauh dari memuaskan. Pada pemilu tahun 1999, jumlah perempuan yang duduk di DPR hanya 44 orang, sementara pada Pemilu 2004 meningkat menjadi 61 orang atau hanya 11,7 persen dari jumlah keseluruhan anggota Dewan (Sawitri, 2010). Pada Pemilu 2009 pun, keterwakilan kaum perempuan tak jauh beda. Secara kuantitatif jumlah tersebut tentu masih jauh dari harapan.Para aktivis perempuan menilai, keterwakilan kaum perempuan dengan jumlah yang memadai tentu akan sangat berimbas pada kebijakan negara.Angka-angka tersebut, sebenarnya sangat tidak sebanding dengan besarnya jumlah perempuan yang turut berpartisipasi dalam Pemilu. Angka keterwakilan perempuan tersebut dapat dilihat dalam Tabel 2 .

Keterwakilan perempuan di parleman untuk Indonesia, ternyata paling rendah jika dibanding-
Namun dalam praktiknya, berbagai ketimpangan selalu dijumpai. Misalnya, masalah buta huruf masih saja dialami kaum perempuan. Bemmelen, misalnya, menyatakan bahwa pada tahun 1991 lebih dari 40 persen perempuan di Asia Tenggara yang berusia 25 tahun atau lebih mengalami buta huruf (Bemmelen dalam Ihromi, 1995: 197). Ketimpangan itu juga dijelaskan dalam studi yang dilakukan Asia Development Bank (ADB) tentang Kebijakan ADB dalam Gender dan Pembangunan (1998). Dari empat aspek yang dikaji yaitu: 1) harapan hidup pada kelahiran; 2) angka melek huruf dewasa; 3) semua tingkat pendidikan, angka pendaftaran kotor; dan 4) bagian pendapatan yang diperoleh menunjukkan bahwa ketimpangan yang dialami perempuan dibandingkan laki-laki masih jauh terjadi. Lebih lengkap dapat dilihat dalam Tabel 3.

Di sisi lain, berdasarkan studi Soemardi (dalam Bemmelen, et.al., 2000: 510) meski persentase perempuan Indonesia (usia 10 tahun ke atas) yang telah berhasil menamatkan SLTP dan tingkat pendidikan yang lebih tinggi meningkat, yaitu naik dari 4,5 persen pada tahun 
Tabel 2. Perbandingan angka keterwakilan perempuan Indonesia dalam DPR

\begin{tabular}{|l|c|c|}
\hline \multicolumn{1}{|c|}{ Masa Kerja DPR } & Perempuan & Laki-Iaki \\
\hline $1950-1955$ (DPR Sementara) & $9(3.8 \%)$ & $236(96.2 \%)$ \\
\hline $1955-1960$ & $17(6.3 \%)$ & $272(93.7 \%)$ \\
\hline Konstituante:1956-1959 & $25(5.1 \%)$ & $488(94.9 \%)$ \\
\hline $1971-1977$ & $36(7.8 \%)$ & $460(92.2 \%)$ \\
\hline $1977-1982$ & $29(6.3 \%)$ & $460(93.7 \%)$ \\
\hline $1982-1987$ & $39(8.5 \%)$ & $460(91.5 \%)$ \\
\hline $1987-1992$ & $65(13 \%)$ & $500(87 \%)$ \\
\hline $1992-1997$ & $62(10.50 \%)$ & $500(87.50 \%)$ \\
\hline
\end{tabular}

Sumber: Cetro, 2002

Tabel 3. Populasi dan Kesehatan; Pendidikan oleh Laki-laki/Perempuan di Indonesia

\begin{tabular}{|c|c|c|c|c|c|c|c|c|c|c|c|}
\hline \multicolumn{2}{|c|}{$\begin{array}{c}\text { Harapan } \\
\text { hidup pada } \\
\text { kelahiran }\end{array}$} & \multicolumn{2}{|c|}{$\begin{array}{c}\text { Angka melek } \\
\text { huruf } \\
\text { dewasa (\%) } \\
1994\end{array}$} & \multicolumn{2}{|c|}{$\begin{array}{l}\text { Perkiraan } \\
\text { angka buta } \\
\text { huruf dewasa } \\
\text { (\%) } 1995\end{array}$} & \multicolumn{2}{|c|}{$\begin{array}{c}\text { Rasio } \\
\text { pendaftaran } \\
\text { primer kotor } \\
\text { (\%) } 1993\end{array}$} & \multicolumn{2}{|c|}{$\begin{array}{c}\text { Rasio } \\
\text { pendaftaran } \\
\text { sekunder } \\
\text { kotor (\%) } \\
1993 \\
\end{array}$} & \multicolumn{2}{|c|}{\begin{tabular}{|c|} 
Rasio \\
pendaftaran \\
kotor terpadu: \\
primer, sekunder \\
tersier (\%) 1994 \\
\end{tabular}} \\
\hline$L$ & $P$ & $L$ & $P$ & $L$ & $P$ & $L$ & $P$ & $\mathrm{~L}$ & $P$ & $L$ & $P$ \\
\hline 65,3 & 61,8 & 77,1 & 89,4 & 10,4 & 22 & 116 & 113 & 47 & 39 & 59 & 65 \\
\hline
\end{tabular}

Sumber: (Anonim, 1998)

1971 menjadi 27,9 persen pada 1998. Kenaikannya hampir enam kali lipat. Namun demikian, angka ini masih jauh di bawah angka laki-laki. Persentase laki-laki yang telah berhasil menamatkan SLTP dan tingkat pendidikan yang lebih tinggi sebesar 9,2 persen pada tahun 1971 menjadi 34,5 persen pada tahun 1998, yaitu hanya berlipat ganda 3,75 kali (Tabel 4).

Meskipun akses pendidikan perempuan semakin meningkat tetapi persentasenya masih di bawah laki-laki. Menurut Soemardi (Bemmelen, 2000: 511), proyeksi hingga 2010 tingkat pencapaian tamat SLTP dan lebih tinggi dapat mencapai 59,9 persen untuk perempuan dan 62,1 persen untuk laki-laki.

Data dari BPS tahun 2003 yang dikutip Sasmita (Jurnal Perempuan Nomor 44, 2005: 15), menyebutkan bahwa penduduk Indonesia yang berusia 10 tahun ke atas yang buta aksara adalah sebesar 15.533.271 penduduk. Jumlah tersebut

Tabel 4. Pencapaian Tingkat Pendidikan SLTP ke atas (Penduduk 10 tahun ke atas)

\begin{tabular}{|c|c|c|c|c|c|}
\hline Tahun & Laki-Laki & Perempuan & Total & $\begin{array}{l}\text { Skor (indeks } \\
\text { Laki-laki 100) }\end{array}$ & $\begin{array}{c}\text { Disparitas } \\
\text { Gender }\end{array}$ \\
\hline 1971 & 9.2 & 4.5 & 6.8 & 49 & 51 \\
\hline 1980 & 13.8 & 7.9 & 10.8 & 57 & 43 \\
\hline 1990 & 25.8 & 18.2 & 21.9 & 70 & 30 \\
\hline 1998 & 34.5 & 27.9 & 30.6 & 75 & 25 \\
\hline \multicolumn{6}{|c|}{ Kenaikan per tahun } \\
\hline $1971-1980$ & 3.2 & 6.5 & 5.3 & & \\
\hline 1981-1990 & 6.5 & 8.7 & 7.3 & & \\
\hline 1991-1998 & 3.7 & 5.1 & 4.3 & & \\
\hline Total & 5.1 & 6.9 & 5.7 & & \\
\hline
\end{tabular}

Sumber: Soemardi dalam Bemmelen (2000: 511) 
terdiri atas penduduk perempuan sebanyak 10.643.823, atau 67,9 persen dan sisanya adalah penduduk laki-laki sebanyak 5.042.338 atau hanya 32,1 persen. Di daerah pedesaan, menurut BPS, kondisinya lebih parah lagi. Jumlah perempuan di pedesaan yang melek huruf sebesar 19,2 persen dan sisanya, 9,63 adalah penduduk laki-laki.

Berdasarkan data dan temuan lapangan itulah menjadikan tema ini tak pernah usang untuk dikaji. Berbagai kajian sejenis yang dilakukan pada dasarnya berupaya membongkar sekaligus menawarkan berbagai solusi dan cara pandang baru terhadap ketimpangan yang ada. Studi yang akan dilakukan ini juga hendak mendiskusikan bagaimana ketimpangan yang terjadi dalam dunia pendidikan. Beberapa studi menunjukkan bahwa, dalam pencapaian prestasi akademik siswa, ternyata juga terjadi ketimpangan. Perempuan, hampir selalu mempunyai prestasi akademik yang lebih rendah dari laki-laki.

Secara lebih spesifik artikel ini akan menjelaskan terjadinya ketimpangan gender melalui perbedaan prestasi akademik antara perempuan dan laki-laki di SMA 12 Bekasi. Artikel ini ini mengkaji terjadinya bias gender di sekolah melalui perbedaan prestasi akademik siswa laki-laki dan perempuan. Prestasi akademik tersebut tidak dilihat secara keseluruhan, namun dilihat melalui perbedaan nilai UAS siswa laki-laki dan perempuan pada tiga mata pelajaran, yaitu Fisika, Sosiologi dan Bahasa Indonesia. Ketiga mata pelajaran tersebut sengaja dipilih guna mewakili karakteristik mata pelajaran, yaitu Fisika (untuk mata pelajaran eksakta); Sosiologi (untuk mata pelajaran noneksakta); dan Bahasa Indonesia (untuk mata pelajaran umum).

Permasalahan yang diangkat dalam penulisan ini yaitu: 1) Apakah ada perbedaan prestasi akademik antara siswa laki-laki dan perempuan pada mata pelajaran Fisika, Sosiologi dan Bahasa Indonesia? 2) Bagaimanakah kecenderungan perbedaan prestasi akademik antara siswa laki-laki dan perempuan pada mata pelajaran Fisika, Sosiologi dan Bahasa Indonesia?

Penulisan artikel ini bertujuan untuk menjelaskan: 1) perbedaan prestasi akademik antara siswa laki-laki dan perempuan pada mata pelajaran Fisika, Sosiologi, dan Bahasa Indonesia;
2) menjelaskan kecenderungan perbedaan prestasi akademik antara siswa laki-laki dan perempuan pada mata pelajaran Fisika, Sosiologi, dan Bahasa Indonesia.

\section{Kajian Pustaka Konstruksi Perempuan dalam Kesetaraan Gender}

Permasalahan perbedaan laki-laki dan perempuan dalam pendidikan dapat dikaji melalui teori struktural fungsional. Secara umum, para analis fungsional, melihat fungsi serta konstribusi yang positif lembaga pendidikan dalam memelihara atau mempertahankan keberlangsungan sistem sosial (Haralambos, 2004: 692). Para penganut teori ini menyatakan bahwa pendidikan merupakan pelatihan guna meningkatkan modal manusia secara individual, yakni keahlian dan kecakapan yang kita peroleh.

Sekolah, menurut Durkhiem (Haralambos, 2004), mempunyai tugas dan fungsi untuk menanamkan nilai-nilai yang bermanfaat guna mempertahankan sistem sosial. Sekolah adalah representasi (miniatur) dari masyarakat. untuk itu, norma-norma yang berlaku di masyarakat juga ditanamkan di sekolah melalui proses sosialisasi. Sebagaimana kita ketahui, di dalam masyarakat, perempuan diposisikan sebagai "orang kedua" dalam struktur hubungan antara laki-laki dan perempuan. Perempuan diharuskan untuk selalu tampil cantik, lemah lembut, halus, sedangkan lakilaki diposisikan sebagai "makhluk" yang kuat sehingga mampu melindungi perempuan. Perempuan tidak dihargai melalui otak atau kecerdasannya, melainkan dari segi fisiknya. Sebaliknya, laki-laki, lebih dihargai dari otak atau kecerdasannya. Oleh karena itulah, tidak banyak perempuan yang menempuh pendidikan sampai tingkat tinggi, karena masih banyak masyarakat yang menganggap "untuk apa perempuan sekolah tinggi-tinggi, jika nantinya akhirnya kembali ke rumah?". Dengan kata lain, masyarakat menganggap bahwa perempuan pada dasarnya hanya bertugas untuk mengurusi masalah sumur, dapur dan kasur (mengurus rumah, memasak dan melayani suami).

Image dan konstruksi yang dibentuk masyarakat, ternyata juga disosialiasikan melalui proses pendidikan. Beberapa stereotype yang 
"merugikan" perempuan tersebut, pada akhirnya menghiasi pola pikir perempuan dalam proses pendidikan. Pada minat pemilihan mata pelajaran, misalnya, perempuan tidak begitu unggul pada bidang studi yang bersifat eksakta, karena mereka menganggap, itu adalah bidang studi yang "berat" dan milik lelaki ${ }^{1}$. Perempuan lebih banyak menyukai mata pelajaran yang memerlukan "kehalusan", misalnya mata pelajaran kesenian (menari), keterampilan tangan dan bahasa, sehingga kedua mata pelajaran ini dianggap mata pelajaran milik perempuan.

Teori struktural fungsional, pada perkembanganya, melahirkan satu aliran feminis, yang dinamakan aliran Feminisme Liberal. Feminisme Liberal berasal dari paradigma fungsionalisme struktural yg dikembangkan oleh Merton dan Parsons. Aliran ini pada awalnya muncul untuk mengkritik teori politik liberal yang menjunjung tinggi nilai otonomi, persamaan, nilai moral serta kebebasan individu, namun di saat yang sama dianggap mendiskriminasi kaum perempuan.

Asumsi dasar feminisme liberal adalah kebebasan (freedom) dan kesamaan (equality) yang berakar pada rasionalitas dan pemisahan antara dunia privat dan publik. Kerangka kerja feminisme liberal adalah memperjuangkan kesempatan dan hak yang sama bagi setiap individu, termasuk di dalamnya kesempatan dan hak kaum perempuan. Kaum perempuan harus dipersiapkan agar bisa bersaing dalam suatu dunia yang penuh dengan persaingan bebas. Sebagian dari usaha ini dapat dilihat dalam program-program perempuan dalam pembangunan (women in development) yakni dengan menyediakan program intervensi guna meningkatkan taraf hidup keluarga seperti pendidikan, keterampilan serta kebijakan yang dapat meningkatkan kemampuan kaum perempuan agar dapat terlibat dalam proses pembangunan (Fakih, 2004: 71-83). Dengan kata lain perubahan yang ingin dicapai oleh aliran ini adalah emansipasi kaum perempuan di seluruh bidang kehidupan, misalkan pendidikan yang setara, keterampilan yang setara serta membuka akses pekerjaan yang sebelumnya hanya dapat dimasuki oleh kaum laki-laki. Pada titik inilah kaum perempuan dapat mengembangkan dirinya di dalam ranah publik dengan menjadi profesional di bidang masing-masing sama halnya dengan laki-laki sebagai mitra kerja yang sejajar dengannya (Tong, 1998: 15-65).

\section{Definisi Bias Gender dalam Pendidikan}

Pengertian gender adalah suatu sifat yang melekat pada kaum laki-laki maupun perempuan yang dikonstruksi secara sosial maupun kultural. Sejarah perbedaan gender (gender differences) antara laki-laki dan perempuan terjadi melalui proses yg sangat panjang, contohnya melalui proses sosialisasi, ajaran keagamaan serta kebijakan negara, sehingga perbedaanperbedaan tersebut seolah-olah dianggap dan dipahami sebagai kodrat laki-laki dan perempuan. Selanjutnya, perbedaan gender dapat menghasilkan bentuk-bentuk marginalisasi, ketidakadilan (gender inequalities), subordinasi, pembentukan stereotipe, beban kerja ganda (double burden) serta bentuk-bentuk kekerasan. Kaum perempuan adalah pihak yg paling sering dirugikan dalam praktek-praktek gender differences ini, maka konsep bias gender dapat diartikan pembentukan sifat atau karakter laki-laki dan perempuan secara sosial dan kultural yang menguntungkan kaum laki-laki dan merugikan kaum perempuan (Fakih, 2004: 3-24). Bias gender ini terjadi pada semua bidang kehidupan, termasuk pendidikan.

Pendidikan di sekolah merupakan sebuah issue signifikan bagi wanita sekarang, karena mereka makin banyak terlibat dalam sejumlah tingkatan dan aneka ragam lingkungan. Mereka mulai dari pendidikan prasekolah dan taman kanak-kanak, hingga sekolah menengah dan barangkali perguruan tinggi dengan bergerak melalui struktur yang sama seperti murid-murid laki-laki. Dalam setiap situasi pendidikan tersebut, murid wanita dan pria sama-sama terbuka untuk buku-buku kelas dan bahan-bahan dan sikap guru yang secara halus dapat mempengaruhi penilaian mereka tentang diri mereka sendiri serta masyarakat. Wanita berpartisipasi dalam bidang studi yang berbeda (seperti lebih banyak mengambil ilmu sastra dan ekonomi rumah tangga daripada eksakta).

Dalam pembelajaran yang dilakukan di kelas, perempuan biasanya identik dengan keterampilan "pekerjaan ibu rumah tangga". Mereka dituntut untuk bersikap tenang, bersifat menghargai, 
penuh perhatian, dapat dipercaya, serta mau bekerja sama. Untuk laki-laki harapan lebih didasarkan pada kriteria kemampuan akademik seperti pengetahuan, kecakapan intelektual, dan kebiasaan kerja (Sucahyono dan Sumaryana, 1996: 150-160).

Beberapa hasil penelitian yang relevan antara lain: Logdson (dalam Muthali'in, 2001: 7), dengan judul "General Roles in Elementary School Texts in Indonesia". Hasil penelitian menunjukkan bahwa, buku-buku teks yang digunakan di SD mengandung konsep gender, sekaligus berperan membakukan peran-peran gender yang harus dilakukan siswa.

Astuti dkk. (dalam Muthali'in, 2001: 6) dengan judul "Bias Gender dalam Buku Pelajaran Bahasa Indonesia". Hasil penelitian tersebut menunjukkan bahwa terdapat pembedaan gender dalam bukubuku Bahasa Indonesia yang dipergunakan di SD, SMP maupun SMA. Peran publik perempuan, dalam buku-buku tersebut, lebih rendah daripada lakilaki serta akses kontrol wanita terhadap kepemilikan barang dan pengambilan keputusan lebih rendah daripada laki-laki.

Soemardi dengan judul "Disparitas Jender dalam Pencapaian Tingkat Pendidikan 1971-1998 dan Proyeksi 2010" (1998). Studi ini menjelaskan ketimpangan perempuan dan laki-laki yang berusia diatas 10 tahun yang berhasil menamatkan SLTP dan tingkat pendidikan yang lebih tinggi. Rekomendasi yang dihasilkan adalah pentingnya pemberdayaan (anak) perempuan terutama di pedesaan merupakan prioritas untuk meningkatkan akses pendidikan perempuan.

Suleeman (dalam Ihromi, 1995), mengkaji posisi perempuan Indonesia dalam pendidikan dengan judul "Pendidikan Wanita di Indonesia". Dalam analisanya, Suleeman banyak mengungkapkan berbagai fakta dan data tentang ketimpangan dan perbedaan jender antara perempuan dan laki-laki dalam dunia pendidikan.

Salah satu kesimpulan pentingnya adalah kemiskinan dianggap sebagai faktor yang dapat menghambat seseorang bersekolah, khususnya bagi perempuan.

Hasil General Certificate of Education (GCE) di Amerika, ternyata menghasilkan data sebagai berikut: 1) Sampai usia 11 tahun. Laki-laki dan perempuan pada umumnya mempunyai tingkat prestasi yang sama; 2) Perbandingan jumlah siswa laki-laki dan perempuan yang memperoleh nilai " $A$ ", pada beberapa mata pelajaran, menunjukkan hasil: Fisika: 6:1; Matematika: 4:1; Kimia: 3:1; Biologi: 9:8; Menggambar: 200:1; Bahasa: $1: 2$; 3) Jumlah laki-laki yang belajar menjadi calon guru, lebih sedikit dibandingkan dengan perempuan, karena profesi guru dianggap profesi perempuan.

\section{Metode Penelitian}

Obyek penelitian ini adalah data sekunder berupa daftar nilai hasil ujian mata pelajaran, yaitu Fisika, Sosiologi dan Bahasa Indonesia. Data nilai yang digunakan adalah hasil UAS tahaun pelajaran 2006-2007 di kelas X SMA 12 Bekasi. Penelitian ini menggunakan pendekatan kuantitatif dengan metode analisis data sekunder (ADS). ADS merupakan suatu metode penelitian dengan memanfaatkan data sekunder sebagai sumber data utama. Data sekunder tersebut diharapkan mampu memberikan informasi yang diperlukan guna menjawab pertanyaan penelitian. Metode pengumpulan data yang digunakan adalah metode dokumentasi. Dokumentasi yang dipergunakan dalam penelitian ini berupa daftar nilai hasil Ujian Akhir Semester (UAS) mata pelajaran Fisika, Sosiologi dan Bahasa Indonesia tahun 2007 di SMA N 12 Bekasi. Metode analisis data yang akan digunakan dalam penelitian ini adalah metode analisis data sekunder. Adapun alat analisis yang akan digunakan adalah tabel distribusi frekuensi dan tabel silang.

Pengolahan data menunjukkan hasil yang berbeda dengan teori maupun hasil studi-studi terdahulu. Dalam beberapa literatur juga menunjukkan bahwa dominasi laki-laki masih sangat kental diberbagai sektor publik dibandingkan perempuan. Fenomena tersebut tidak terlepas dari pengaruh faktor agama, budaya etnis dan peraturan pemerintah (Muthali'in 2001: 4449). Sehingga, pola pikir masyarakat terbentuk oleh faktor-faktor tersebut yang menyebabkan terjadinya bias gender. Seiring perkembangan zaman, pola pikir (nilai-nilai) masyarakat mulai berubah. Kini, mereka sadar bahwa bias gender yang terjadi di lingkungan masyarakat selama ini dapat melahirkan ketidakadilan pada perempuan.

Di Eropa, kesadaran terhadap ketidakadilan 
terhadap perempuan, sudah terjadi sejak lama yang kemudian melatarbelakangi munculnya gerakan feminisme. Menurut Bashin dan Khan (Muthali'in, 2001: 45), munculnya gerakan feminisme merupakan suatu kesadaran akan penindasan dan pemerasan terhadap perempuan dalam masyarakat. Kesadaran tersebut nampak terlihat jelas terutama dalam lingkungan masyarakat kota yang lebih kosmopolitan.

Berkaitan dengan itu, lokasi penelitian ini berada di Kota Bekasi. Sebagai kota satelit DKI Jakarta, masyarakat Bekasi mengalami perkembangan yang cepat. Perkembangan ini selanjutnya mempengaruhi pola pikir masyarakat, sehingga beberapa pandangan yang mengandung bias gender mulai ditinggalkan. Masyarakat sudah menerima persamaan kedudukan laki-laki dan perempuan, baik dalam sektor publik maupun privat. Sekolah sebagai miniatur masyarakat, pada akhirnya juga merespon dengan jalan mengadopsi nilai-nilai yang berkembang di masyarakat sekitar. Pengadopsian ini diwujudkan melalui proses pembelajaran yang berbasis gender. Misalnya, ketua atau pemimpim organisasi intra sekolah tidak lagi harus dijabat oleh seorang laki-laki. Atau sebaliknya jabatan sekretaris dan bendahara tidak harus dipegang oleh perempuan. Sekarang, laki-laki maupun perempuan mendapat kesempatan yang sama dalam hal; megemukakan pendapat, kesempatan untuk lebih berprestasi, diberi kebebasan untuk memilih bakat dan sebagainya.

Selain itu, peran media massa juga turut membantu dalam mensosialisasikan mengenai kesetaran gender. Akibatnya, para orang tua mulai mempunyai kesadaran untuk menyekolahkan anak perempuannya, sampai ke tingkat yang lebih tinggi dengan tidak memilah-milah jurusan tertentu. Misalnya, Fakultas Teknik yang dulu diyakini sebagai fakultas bagi laki-laki, sekarang banyak dipilih oleh perempuan. Jurusan bahasa dan FKIP, yang dulu banyak diminati oleh perempuan, kini diminati juga oleh laki-laki. Profesi sebagai wartawan, insinyur, hakim, dan berbagai cabang olahraga seperti tinju, sepak bola, angkat besi, bela diri bahkan supir bus way pun mulai disandang oleh perempuan. Di sisi lain, profesi guru (terutama guru TK), juru masak, tata rias, penjahit juga sudah digeluti oleh laki-laki.
Sementara itu, media massa juga memberi sumbangan yang besar dalam mendombrak pola pikir masyarakat. Diberbagai tayangan televisi, sosok perempuan digambar sebagai wanita karir yang mandiri. Mereka juga mulai memiliki kesadaran untuk tidak lagi memposisikan dirinya sebagai "manusia kedua" dalam struktur hubungan laki-laki dan perempuan yang pada akhirnya mampu tampil di ruang publik yang selama ini didominasi oleh laki-laki. Hal tersebut selaras dengan Teori Nurture, dimana teori ini tidak setuju bahwa pemilihan posisi dan peran antara laki-laki dan perempuan merupakan kodrat alam (Muthali'in, 2001: 24). Selain teori Nerture, teori kebudayaan dengan perspektif materialis menjelaskan bahwa terjadinya keunggulan lakilaki terhadap perempuan, karena dokontruksi oleh budaya. Perempuan memiliki hak dan kontribusi yang sama dalam memenuhi kebutuhan ekonomi.

Hal senada juga dijelaskan aliran Feminisme Liberal yang menuntut kebebasan (freedom) dan kesamaan (equality). Feminisme menganggap bahwa kaum perempuan harus dipersiapkan agar bisa bersaing dalam suatu dunia yang penuh dengan persaingan bebas. Sebagian dari usaha ini dapat dilihat dalam program-program perempuan dalam pembangunan (women in development) yakni dengan menyediakan program intervensi guna meningkatkan taraf hidup keluarga seperti pendidikan, keterampilan serta kebijakan yang dapat meningkatkan kemampuan kaum perempuan agar dapat terlibat dalam proses pembangunan (Fakih, 2004: 71-83).

\section{Simpulan dan Saran Simpulan}

Pada mata pelajaran Fisika, perempuan mempunyai nilai yang lebih tinggi dibanding laki-laki. Pada mata pelajaran Sosiologi dan Bahasa Indonesia, tidak terdapat perbedaan yang signifikan antara laki-laki dan perempuan. Hasil penelitian ini dipengaruhi oleh perkembangan pola pikir atau perubahan nilai-nilai yang dianut masyarakat berkaitan posisi perempuan dalam masyarakat. Sekolah sebagai miniatur masyarakat, pada akhirnya juga merespon dengan jalan mengadopsi nilai-nilai yang berkembang di masyarakat sekitar. Pengadopsian ini diwujudkan melalui proses pembelajaran yang berbasis 
gender. Media massa turut mensosialisasikan perlunya kesetaran gender, sehingga orang tua mulai mempunyai kesadaran untuk menyekolahkan anak perempuannya, sampai ke tingkat yang lebih tinggi dengan tidak memilah-milah jurusan tertentu.

\section{Saran}

Berdasarkan pembahasan diatas perlu dilakukan sosialisasi secara intensif sejak dini kepada pelajar tentang kesetaraan gender baik melalui kurikulum formal maupun melalui kegiatan-kegiatan diluar kurikulum formal. Misalnya, kegiatan sejak dini tersebut dapat dilakukan melalui pelajaranpelajaran kepada siswa Sekolah Dasar. Kegiatan di luar kurikulum antara lain dengan penyuluhan, pemutaran film, permainan yang menarik dan edukatif dengan tetap menyampaikan pesan kesetaraan gender kepada pelajar terutama pelajar sekolah dasar. Kegiatan ini dapat melibatkan pihak eksternal seperti Perguruan Tinggi, lembaga swadaya masyarakat (LSM), organisasi kepemudaan dan organisasi kemahasiswaan (seperti Badan Eksekutif Mahasiswa).

\section{Pustaka Acuan}

Anonim. 1998. Kebijakan ADB mengenai Gender dan Pembangunan Asian Development Bank (dokumen tidak diterbitkan).

Bemmelen, Sita Van, Setyawati, Lugina, Habsjah Atashendartini, 2000. Benih Bertumbuh: Kumpulan Karangan untuk Prof. Tapi Omas Ihromi. Jakarta: Kelompok Perempuan Pejuang Perempuan Tertindas.

Cetro. 2002. Data dan Fakta: Keterwakilan Perempuan Indonesia di Partai Politik dan Lembaga Legislatif, 1999 -2001 (Executive Summary). Tidak dipublikasikan

Fakih, Mansour. 2004. Analisis Gender dan Transformasi Sosial. Yogyakarta: Pustaka Pelajar.

Haralambos and Holborn. 2004. Sociology: Themes and Perspectives (Sixth Edition). London: Harper Collins Publisher.

Ihromi, T.O (Penyunting).1995. Kajian Wanita dalam Pembangunan. Jakarta: Yayasan Obor Indonesia Muthali'in, 2001. Bias Gender dalam Pendidikan. Surakarta: Muhammadiyah University Press.

Sawitri, Karuni Ayu, 2010. Perempuan Meretas Hak Politik artikel dalam Harian Suara Karya Sucahyanto, Budi dan Sumaryana, Yan., 1996. Sosiologi Wanita (Terjemahan). Jakarta: Rineka Cipta Tong, Rosemarie Putnam. 1998. Feminist Thought (terjemahan). Yogyakarta: Penerbit Jala Sutera. Undang-Undang Dasar Republik Indonesia Tahun 1945 